\title{
MERIT FUNCTION FOR VARIATIONAL-LIKE INEQUALITIETS
}

\author{
MuHAMMAD ASLAm NOOR
}

Abstract. In this paper, we use the auxiliary principle technique to suggest an iterative method and a merit function for variational-like inequalities. Several special cases, which can be obtained from our results, are also discussed.

Mathematics subject classification (1991): 49J40, 90C33.

Key words and phrases: Variational-like inequalities, merit functions, iterative method, error estimate.

\section{REFERENCES}

[1] C. BAIOCCHI AND A. CAPELO, Variational and Quasi-Variational Inequalities, J. Wiley and Sons, New York, 1984.

[2] A . Ben-Israel And B. Mond, What is invexity? J. Austral. Math. Soc. Series B. 28 (1986), 1-9.

[3] E. Blum AND W. OETTLI, From optimization and variational inequalities to equilibrium problems, Math. Student 63 (1994), 123-145.

[4] G. Y. CHEN, C. J. GOH AND X. Q. YANG, On gap functions and duality of variational inequality problems, J. Math. Anal. Appl. 224 (1997), 658-673.

[5] J. ECKSTEIN, Nonlinear proximal point algorithms using Bregman functions with applications to convex programming, Math. Opers. Research 18 (1993), 202-226.

[6] J. ECKSTEIN, Approximate iterations in Bregman-function-based proximal algorithms, Math. Program. 83 (1998), 113-123.

[7] M. FuKUSHIMA, Equivalent differentiable optimization problems and descent methods for asymmetric variational inequality problems, Math. Program. 53 (1992), 99-110.

[8] F. GianNessi AND A. MAUgerI, Variational Inequalities and Network Equilibrium Problems, Plenum Press, New York, 1995.

[9] R. Glowinski, J. L. Lions and R. TRemolieres, Numerical analysis of variational inequalities, North-Holland, Amsterdam, 1981.

[10] R. GLOWINSKI, Numerical methods for nonlinear variational problems, Springer-Verlag, Berlin, New York, 1985.

[11] M. A. HAnson, On sufficiency of the Kuhn-Tucker conditions, J. Math. Anal. Appl. 80 (1981), 545-550.

[12] D. H. Hyers, G. IsAC AND TH. M. Rassias, Topics in Nonlinear Analysis and Applications, World Scientific Publ. Co. Singapore, 1997.

[13] N. KikUCHI AND J. T. OdEn, Contact Problems in Elasticity, SIAM Publishing Co., Philadelphia, 1988.

[14] D. Kinderlehrer AND G. Stampacchia, An Introduction to Variational Inequalities and Their Applications, Academic Press, London, 1980.

[15] T. LARSSON AND M. PATRIKSSON, A class of gap functions for variational inequality, Math. Program. 64 (1994), 53-79.

[16] M. ASLAM NoOR, Variational-like inequalities, Optimization 30 (1994), 323-330.

[17] M. Aslam Noor, Preinvex functions and variational inequalities, J. Nat Geometry 9 (1996), 63-76.

[18] M. Aslam Noor, General nonlinear mixed variational-like inequalities, Optimization 37 (1996), 357-367.

[19] M. Aslam Noor, Nonconvex functions and variational inequalities, J. Optim. Theory Appl. 87 (1995), 615-630.

[20] M. Aslam Noor, Auxiliary principle for generalized mixed variational-like inequalities, J. Math. Anal. Appl. 215 (1997), 75-85. 
[21] M. Aslam NoOR, Some recent advances in variational inequalities,Part I, basic concepts, New Zealand J. Math. 26 (1997), 53-80.

[22] M. Aslam NoOR, Some recent advances in variational equalities, Part II, other concepts, New Zealand J. Math. 26 (1997), 229-255.

[23] M. A. NOOR, K. I. NOOR AND TH. M. Rassias, Some aspects of variational inequalities, J. Comput. Appl. Math. 47 (1993), 285-312.

[24] J. PARIDA AND A. SEN, A variational-like inequality for multifunctions with applications, J. Math. Anal. Appl. 124(1987), 73-81.

[25] G. Stampacchia, Formes bilineaires coercitives sur les ensembles convexes, C. R. Acad. Sci. Paris 258 (1964), 4413-4416.

[26] G. TIAN, Generalized quasi variational-like inequality problem, Math. Opers. Research 18 (1993), $752-764$.

[27] X. Q. YANG AND G. Y. ChEN, A class of nonconvex functions and pre-variational inequalities, J. Math. Anal. Appl. 169 (1992), 359-373.

[28] J. C. YAO, The generalized quasi variational inequality problem with applications, J. Math. Anal. Appl. 158 (1991), 139-160.

[29] T. WeIR AND B. Mond, Preinvex functions in multiobjective optimization, J. Math. Anal. Appl. 136 (1988),29-38.

[30] D. L. ZHU AND P. MARCotTE, An extended descent framework for variational inequalities, J. Optim. Theory Appl. 80 (1996), 349-366.

[31] D. L. ZhU AND P. MARCotTE, Co-coercivity and its role in the convergence of iterative schemes for solving variational inequalities, SIAM J. Optim. 6 (1996), 714-726. 